\title{
Explosive pleuritis
}

\author{
Jasdeep K Sharma BSc MD, Thomas J Marrie MD FRCP
}

\begin{abstract}
JK Sharma, TJ Marrie. Explosive pleuritis. Can J Infect Dis 2001;12(2):104-107.
The objective of the present paper is to describe the clinical and computed tomography features of 'explosive pleuritis', an entity first named by Braman and Donat in 1986, and to propose a case definition. A case report of a previously healthy, 45year-old man admitted to hospital with acute onset pleuritic chest pain is presented. The patient arrived at the emergency room at 15:00 in mild respiratory distress; the initial chest x-ray revealed a small right lower lobe effusion. The subsequent clinical course in hospital was dramatic. Within $18 \mathrm{~h}$ of admission, he developed severe respiratory distress with oxygen desaturation to $83 \%$ on room air and dullness of the right lung field. A repeat chest x-ray, taken the morning after admission, revealed complete opacification of the right hemithorax. A computed tomography scan of the thorax demonstrated a massive pleural effusion with compression of pulmonary tissue and mediastinal shift. Pleural fluid biochemical analysis revealed the following concentrations: glucose $3.5 \mathrm{mmol} / \mathrm{L}$, lactate dehydrogenase $1550 \mathrm{U} / \mathrm{L}$, protein $56.98 \mathrm{~g} / \mathrm{L}$, amylase $68 \mathrm{U} / \mathrm{L}$ and white blood cell count 600 cells/mL. The pleural fluid cultures demonstrated light growth of coagulase-negative staphylococcus and viridans streptococcus, and very light growth of Candida albicans. Cytology was negative for malignant cells. Thoracotomy was performed, which demonstrated a loculated parapneumonic effusion that required decortication. The patient responded favourably to the empirical administration of intravenous levofloxacin and ceftriaxone, and conservative surgical methods in the management of the empyema. This report also discusses the patient's rapidly progressing pleural effusion and offers a potential case definition for explosive pleuritis. Explosive pleuritis is a medical emergency defined by the rapid development of a pleural effusion involving more than $90 \%$ of the hemithorax over $24 \mathrm{~h}$, which causes compression of pulmonary tissue and mediastinal shift to the contralateral side.
\end{abstract}

Key Words: Explosive pleuritis; Pleurisy; Pleuritis; Pneumonia

\section{Pleurésie fulgurante}

RÉSUMÉ : Le présent article vise à décrire le tableau clinique de la pleurésie fulgurante, désignée ainsi la première fois par Braman et Donat en 1986, et ses caractéristiques à la tomodensitométrie, en plus de proposer une définition. Voici le cas d'un homme de 45 ans, en bonne santé auparavant, hospitalisé pour une douleur thoracique d'apparition brutale due à une pleurésie. Le patient est arrivé à l'urgence à $15 \mathrm{~h}$ et présentait une légère détresse respiratoire; la première radiographie thoracique a révélé un petit épanchement du lobe inférieur droit. Son état clinique s'est détérioré très rapidement par la suite. Dix-huit heures après son admission, une détresse respiratoire grave s'est installée avec une désaturation du sang en oxygène de 83 \% à l'air ambiant et une matité du poumon droit. Une deuxième radiographie prise le lendemain de son admission montrait une opacification complète de l'hémithorax droit. Une tomodensitométrie du poumon a révélé un épanchement pleural massif avec compression des tissus pulmonaires et déplacement du médiastin. L'analyse biochimique du liquide pleural était comme suit : glucose : 3,5 mmol/1; lacticodéshydrogénase : $1550 \mathrm{U} / \mathrm{l}$; protéines : 56,98 g/l; amylase : $68 \mathrm{U} / \mathrm{l}$ et globules blancs : 600 globules/ml. Les cultures du liquide pleural montraient une légère croissance de staphylocoques à coagulase négative et de Streptococcus viridans ainsi qu'une très légère croissance de Candida albicans. La cytologie a révélé l'absence de cellules malignes. Une thoracotomie a été pratiquée et a laissé voir un épanchement parapneumonique loculé, qui a dû être décortiqué. Le patient a bien réagi à l'administration empirique de lévofloxacine et de ceftriaxone par voie intraveineuse et à l'intervention chirurgicale conservatrice pour le traitement de l'empyème. L'article présente également une discussion sur la progression rapide de l'épanchement pleural et offre une définition possible de la pleurésie fulgurante. Il s'agit d'une urgence médicale qui se caractérise par l'apparition rapide d'un épanchement pleural touchant plus de $90 \%$ de l'hémithorax en $24 \mathrm{~h}$ et qui entraîne une compression des tissus pulmonaires et un déplacement du médiastin vers le côté controlatéral.

Department of Medicine, University of Alberta

Correspondence: Dr Thomas J Marrie, Department of Medicine, University of Alberta, 2F1.30 WMC, 8440-112 Street, Edmonton, Alberta T6G $2 B 7$.

Telephone 780-407-6234, fax 780-407-3132, e-mail tom.marrie@ualberta.ca

Received for publication October 25, 1999. Accepted April 5, 2000 
A 45-year-old man presented to the emergency department at 15:00 with acute onset, right-sided pleuritic chest pain. He was a mechanical pipefitter who had had an upper respiratory tract infection approximately one-and-a-half weeks before presentation. On the day of admission, he developed a productive cough and severe, right-sided pleuritic chest pain.

His past medical history was unremarkable except for a similar episode of chest pain two months earlier, which had been diagnosed as pneumonia. At that time, he was treated with a 10-day course of antibiotics, and his symptoms resolved completely. He had no history of cardiac disease, recent travel, tuberculosis, deep vein thrombosis or pulmonary embolus. The patient smoked one pack of cigarettes per day and drank alcohol on weekends. His only medication was acetaminophen.

On initial physical examination, he was in mild respiratory distress. The patient's temperature was $37.9^{\circ} \mathrm{C}$, blood pressure was 150/88 $\mathrm{mmHg}$, pulse was 132 beats/min, respiratory rate was 36 breaths/min and oxygen saturation was 95\% when breathing room air. Respiratory examination revealed an occasional wheeze, decreased tactile fremitus, egophony and diminished air entry at the right base. The right calf was approximately $2 \mathrm{~cm}$ greater in circumference than the left calf.

Initial laboratory investigations revealed the following: white blood cell count $16.3 \times 10^{9} / \mathrm{L}$, hemoglobin 138 , mean cell volume $89.5 \mathrm{~mm}^{3}$, mean cell hemoglobin $30.8 \mathrm{~g} / \mathrm{dL}$, granulocytes $85 \%$ and platelets $233 \times 10^{9} / \mathrm{L}$. Analysis of the arterial blood gas yielded the following: $\mathrm{pH} 7.41$, partial pressure of carbon dioxide $36 \mathrm{mmHg}$, partial pressure of oxygen $64 \mathrm{mmHg}$, bicarbonate $22 \mathrm{mmol} / \mathrm{L}$, base excess -2 and blood oxygen saturation $93 \%$ while breathing room air. The electrolytes, blood urea nitrogen and creatinine, were normal. The D-dimer was negative, and the creatine kinase level was normal. Serology for hepatitis B and C was negative. Electrocardiogram indicated sinus tachycardia. The chest roentgenogram revealed lateralization of the apex of the right diaphragm, parenchymal changes in lower right lung field due to either atelectasis or air space disease, and blunting of the right costophrenic angle. The lateral chest x-ray revealed a right lower lobe infiltrate with pleural effusion. The patient was started on a course of intravenous levofloxacin $500 \mathrm{mg}$ daily for a diagnosis of community-acquired pneumonia.

At approximately 08:00 on the second day of admission, the patient developed sudden, increasing shortness of breath and worsening pleuritic chest pain. His oxygen saturation dropped to $83 \%$, and he was started on $4 \mathrm{~L} / \mathrm{min}$ oxygen via nasal prongs. A duplex ultrasound of the right leg was negative for deep vein thrombosis. His clinical examination demonstrated dullness to percussion in three-quarters of the posterior right lung field, and a repeat chest $\mathrm{x}$-ray revealed complete opacification of the right hemithorax. A ventilationperfusion study indicated low probability of pulmonary embolism. He received only a short course of intravenous heparin, and his hemoglobin level remained stable. Later the same day, a computed tomography scan of the thorax was performed, which revealed a massive right pleural effusion,

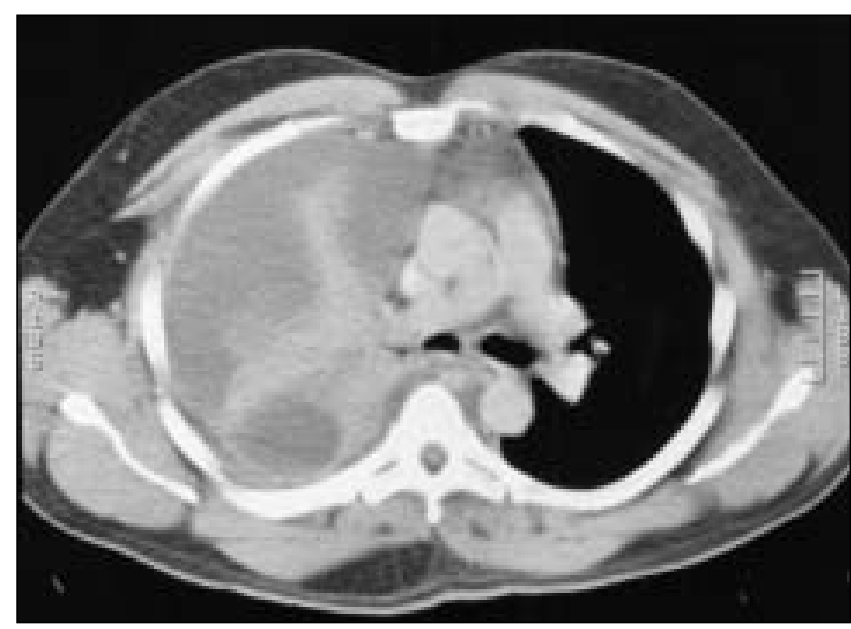

Figure 1) Computed tomography scan of the thorax performed the same day highlights the following: massive fluid accumulation in the right hemithorax and extending across the mediastinum (as noted by the dark shade); impressive compression of the lung tissue (noted by the light shade); and shift of the mediastinum, best seen by the displacement of the carina from midline

compression of the right lung, narrowing of the right main stem bronchus and a shift of the mediastinum to the contralateral side (Figure 1). The antibiotic coverage was expanded with the addition of intravenous ceftriaxone $1 \mathrm{~g}$ bid to the existing levofloxacin. A chest tube was inserted because of his expanding pleural effusion, and postprocedure, he required face mask ventilation with $50 \%$ to $100 \%$ forced inspiratory oxygen. Approximately $500 \mathrm{~mL}$ of serosanguinous fluid was drained and sent for chemistry, culture and cytology. Pleural fluid analysis revealed: glucose $3.5 \mathrm{mmol} / \mathrm{L}$, lactate dehydrogenase $1550 \mathrm{U} / \mathrm{L}$, total protein $56.980 \mathrm{~g} / \mathrm{L}$, amylase $68 \mathrm{U} / \mathrm{L}$, white blood cell count 600 cells $/ \mathrm{mm}^{3}$. Additional serum laboratory measurements were: glucose $6.9 \mathrm{mmol} / \mathrm{L}$, calcium $2.00 \mathrm{mmol} / \mathrm{L}$, magnesium $0.91 \mathrm{mmol} / \mathrm{L}$, albumin $23 \mathrm{~g} / \mathrm{L}$, total protein $48 \mathrm{~g} / \mathrm{L}$, direct bilirubin $7 \mathrm{mmol} / \mathrm{L}$, total bilirubin $11 \mathrm{mmol} / \mathrm{L}$, alanine aminotransferase $29 \mathrm{U} / \mathrm{L}$, aspartate aminotransferase $23 \mathrm{U} / \mathrm{L}$, lactate dehydrogenase $108 \mathrm{U} / \mathrm{L}$, amylase $21 \mathrm{U} / \mathrm{L}$ and antistreptolysin-O titre less than $25 \mathrm{U} / \mathrm{mL}$. Cultures of pleural fluid revealed light growth of coagulasenegative staphylococcus and viridans streptococcus, and very light growth of Candida albicans. Viral cultures were negative. Tumour markers for alfafetoprotein and human chorionic gonadotropin were negative. Cytology was also negative.

On the fourth day of hospitalization, the patient was intubated and transferred to the intensive care unit for respiratory support following the bronchoscopy.

On the fifth day, the patient continued to deteriorate clinically and his hemoglobin level dropped from 138 to $101 \mathrm{~g} / \mathrm{L}$. He underwent a right thoracotomy under general anesthetic and was found to have a loculated parapneumonic effusion that required decortication and chest tube drainage. He remained in the intensive care unit until the eighth hospital day. The patient remained an additional five days in hospital on antibiotics, during which his chest tube was removed and he began to ambulate. 
TABLE 1

Features of the reported cases of 'explosive pleuritis'

\begin{tabular}{|c|c|c|c|c|c|c|c|c|c|c|}
\hline $\begin{array}{l}\text { Year } \\
\text { reported }\end{array}$ & $\begin{array}{c}\text { Age } \\
\text { (years) }\end{array}$ & Sex & $\begin{array}{l}\text { Immuno- } \\
\text { suppresion }\end{array}$ & $\begin{array}{c}\text { Duration between } \\
\text { onet of symptoms and } \\
\text { hospital admission (h) }\end{array}$ & $\begin{array}{c}\text { Pleural } \\
\text { fluid cell } \\
\text { count }(/ \mathrm{mL})\end{array}$ & $\begin{array}{l}\text { Pleural fluid } \\
\text { culture result }\end{array}$ & $\begin{array}{c}\text { Surgical } \\
\text { intervention }\end{array}$ & $\begin{array}{l}\text { Length } \\
\text { of stay } \\
\text { (days) }\end{array}$ & Outcome & Comments \\
\hline 1998 & 45 & Male & None & 24 & 600 & Contaminants & $\begin{array}{l}\text { Thoracostomy } \\
\text { and chest tube }\end{array}$ & 13 days & Discharged & \\
\hline 1985 & 29 & Female & None & 72 & 8500 & $\begin{array}{l}\text { Heavy growth } \\
\text { of group A } \\
\text { beta-hemolytic } \\
\text { streptococci }\end{array}$ & Chest tube & 16 days & Discharged & $\begin{array}{c}\text { Three months } \\
\text { postpartum }\end{array}$ \\
\hline 1985 & 33 & Male & None & 48 & 880 & $\begin{array}{c}\text { Group A } \\
\text { beta-hemolytic } \\
\text { streptococci }\end{array}$ & Chest tube & 17 days & Discharged & \\
\hline
\end{tabular}

Histological examination of the material removed at the time of surgery showed acute fibrinous debris with acute inflammatory cells and early organization consistent with lining of empyema. The serum antistreptolysin-O titre was negligible at $25 \mathrm{U} / \mathrm{mL}$ or less.

On the 13th hospital day, the patient was discharged home with a follow-up appointment in two weeks with the thoracic surgery clinic.

\section{DISCUSSION}

'Explosive pleuritis' was originally described, but not defined, by Braman and Donat (1) in 1986 as pleural effusions developing within hours of admission. In their original article, clinical and roentgenographic evidence for two cases of explosive pleuritis caused by group A beta-hemolytic streptococci, in the absence of bronchopneumonia, were presented (Table 1).

The clinical presentation of explosive pleuritis is fever, dyspnea, pleuritic chest pain and cough. It may also include hemoptysis. Physical examination is consistent with variable degrees of respiratory distress and respiratory system findings of pleural effusion. Laboratory results may confirm an elevated polymorphonulear leukocytosis. If there is a fourfold rise in antistreptolysin-O titre over several weeks or if a single titre is more than 250 Todd units, then the diagnosis of group A beta-hemolytic streptococcal pneumonia may be confirmed (2). Chest radiographic findings reveal pleural effusions, which may or may not be loculated. The findings from the computed tomography scan of the thorax allow for the most accurate measurement of the extent and nature of the massive pleuritis.

The differential diagnosis for pleural effusions consists of infected and noninfected causes. The direct examination of the pleural fluid is necessary to make a definitive diagnosis. The gross histology may not necessarily reveal frank pus. Microscopic analysis would show acute inflammatory reaction and would be consistent with an exudate. The pleural fluid protein concentrations would be greater than $3 \mathrm{~g} / \mathrm{dL}$ and the lactic dehydrogenase level would be greater than $550 \mathrm{U}$. Other characteristics include pleural fluid acidosis, depressed glucose levels and leukocytosis of more than $5000 / \mathrm{mL}$. Evaluation with Gram stain may suggest the causative organism, and cultures of the pleural fluid for both aerobic and anaerobic infection should be used to characterize the organism.

The organisms implicated in explosive pleuritis include the broad spectrum of organisms responsible for major causes of pulmonary infection. These include Gram-positive cocci such as Streptococcus pneumoniae, Streptococcus pyogenes, other streptococci and staphylococci. Gram-negative cocci such as Neisseria meningitidis and Moraxella catarrhalis are also included. Gram-negative bacilli include Hemophilus influenza, Klebsiella pneumoniae, Pseudomonas species, Escherichia coli, Proteus species, Enterobacter species, Bacteroides species and Legionella species. In addition, mycobacteria, fungi, mycoplasma, chlamydiae, rickettsiae and viruses may be causative agents.

Bacteria may reach the pleural space by a variety of mechanisms. The development of empyema results when there is direct spread of bronchopulmonary infections, including pneumonias, lung abscesses and bronchiectasis (3). Other causes include open chest trauma, which may be iatrogenic from a complication of a thoracotomy. As well, intra-abdominal infections, such as subphrenic abscesses, can pass through the diaphragm to cause empyema.

One mechanism that has been proposed for the pathogenesis of explosive pleuritis relates to the observation that streptococcal infections have a unique propensity to cause blockage of the peribronchial and subpleural lymphatics with cellular and necrotic debris (1).

The diagnosis and treatment of this condition make thoracotomy essential. Thoracentesis alone is ineffective. Although rapidly developing pleural effusions are best treated by early chest tube drainage because of a tendency toward early loculation, it is not unusual to have only minimal fluid drained from the pleural space (4). The combination of antimicrobial prophylaxis and the selective, individualized use of conservative surgical methods are the modalities found to be the most effective in the management of empyema (4). They are also the treatments to be used in managing explosive pleuritis.

In our patient, despite the exhaustive workup of cultures, no specific etiological agent was identified. As noted earlier, the microbiology cultures taken from the pleural fluid (but not repeated at the time of decortication) did grow several organisms; however, these were felt to be contaminants. These organisms were polymicrobial in nature, did not grow 
in the primary culture (except for the specimen that was inoculated into broth, which required four days for growth) and were not the usual pathogens for empyema secondary to community-acquired pneumonia. Unfortunately, lung tissue was not found in any specimens taken at the time of the thoracotomy, and hence, the histopathology of the peribronchial lymphatics could not be evaluated.

The initiation of antibiotics at an early stage may have been responsible for the inability to isolate the causative bacterial organism from either the blood, sputum or pleural fluid cultures. However, the rapid progression of the radiographic findings, correlated with the sudden clinical deterioration, warranted aggressive administration of broad spectrum antibiotics at an early stage. The source of pleural infection in this case was likely an inhaled inoculum that was not clearly apparent as pneumonia. The computed tomography scans of the thorax suggested the possibility of an obstructive, intraluminal lesion at the level of the division of the main stem bronchus. Fortunately, bronchoscopy clearly demonstrated the absence of any obstructive mass. The definitive therapy included antimicrobial prophylaxis, thoracotomy, decortication of the loculated parapneumonic effusion and chest tube drainage.

The progression of clinical and radiographic findings are characteristic in explosive pleuritis. The time course is rapid and, by our definition, within $24 \mathrm{~h}$, the pleural effusion expands to involve more than $90 \%$ of the hemithorax and results in the compression of pulmonary tissue with a mediastinal shift to the contralateral side.

\section{SUMMARY}

The present case illustrates several unique features of a rapidly progressive pleural effusion. The authors define explosive pleuritis as the rapid development of pleural effusion involving more than $90 \%$ of the hemithorax within $24 \mathrm{~h}$, causing the compression of pulmonary tissue and a mediastinal shift to the contralateral side. Explosive pleuritis is a medical emergency that demands prompt investigation and early treatment. A combination of appropriate broad spectrum antibiotics and individualized conservative surgical intervention can be life-saving.

\section{REFERENCES}

1. Braman SS, Donat WE. Explosive pleuritis. Am J Med 1986;81:723-6.

2. Lerner AM, Jankauskas $\mathrm{K}$. The classic bacterial pneumonias. Dis Mon 1975;1-46.

3. Bryant RE, Salmon CJ. Pleural empyema. Clin Infect Dis 1996:22;747-62.

4. Thomas DF, Glass JL, Baisch BF. Management of streptococcal empyema. Ann Thorac Surg 1966;2;658-64. 


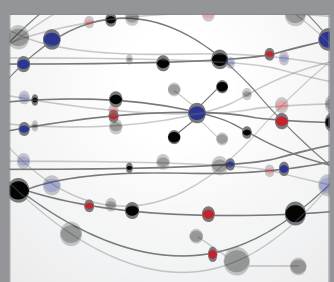

The Scientific World Journal
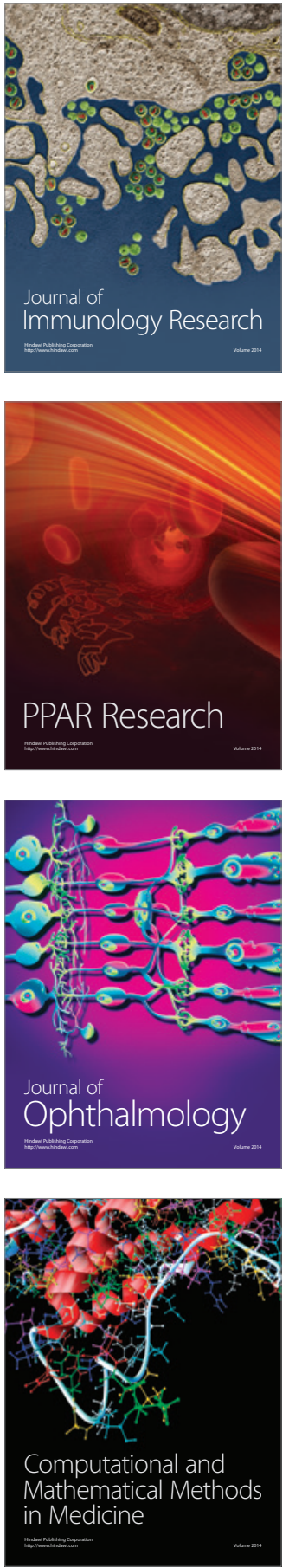

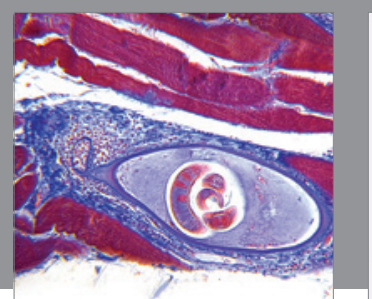

Gastroenterology Research and Practice

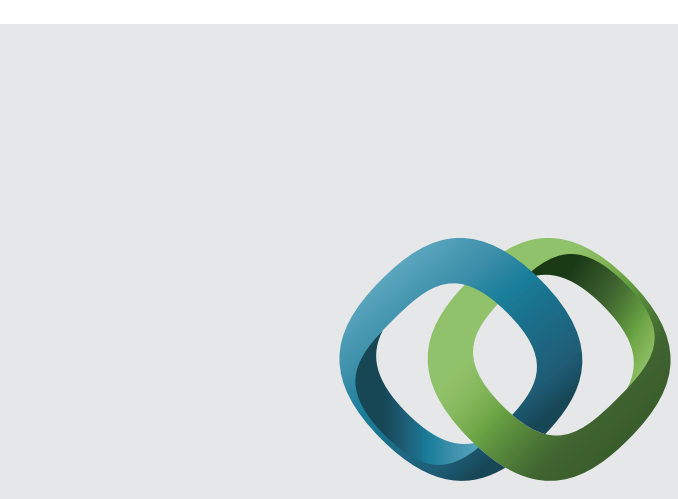

\section{Hindawi}

Submit your manuscripts at

http://www.hindawi.com
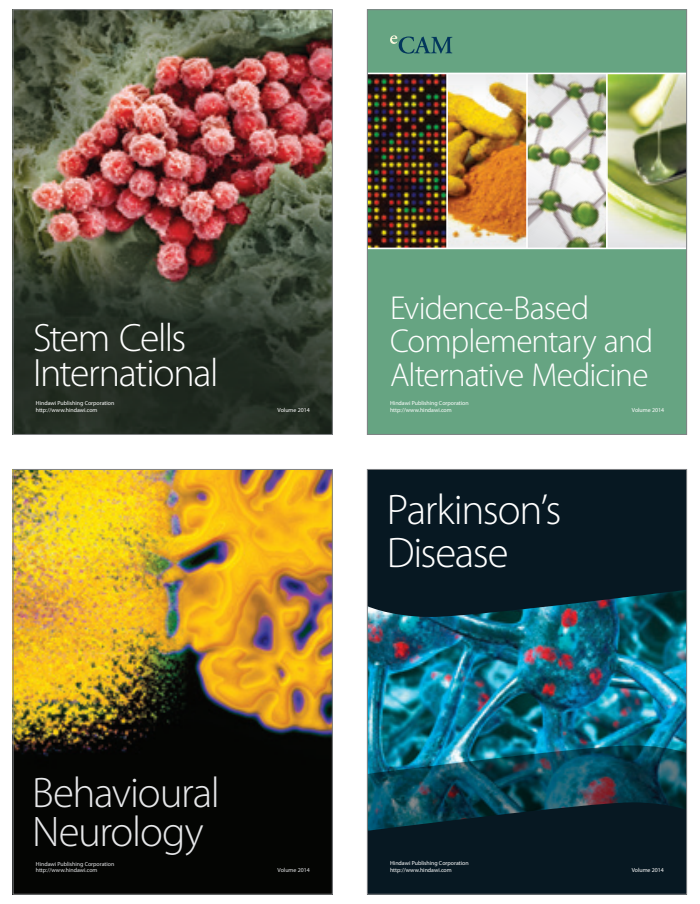
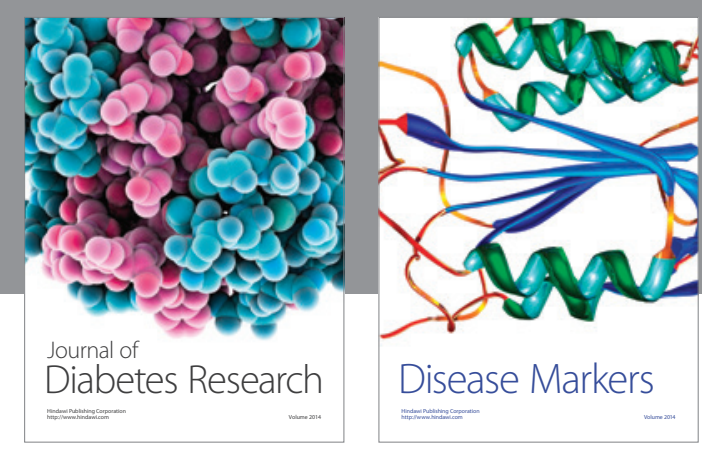

Disease Markers
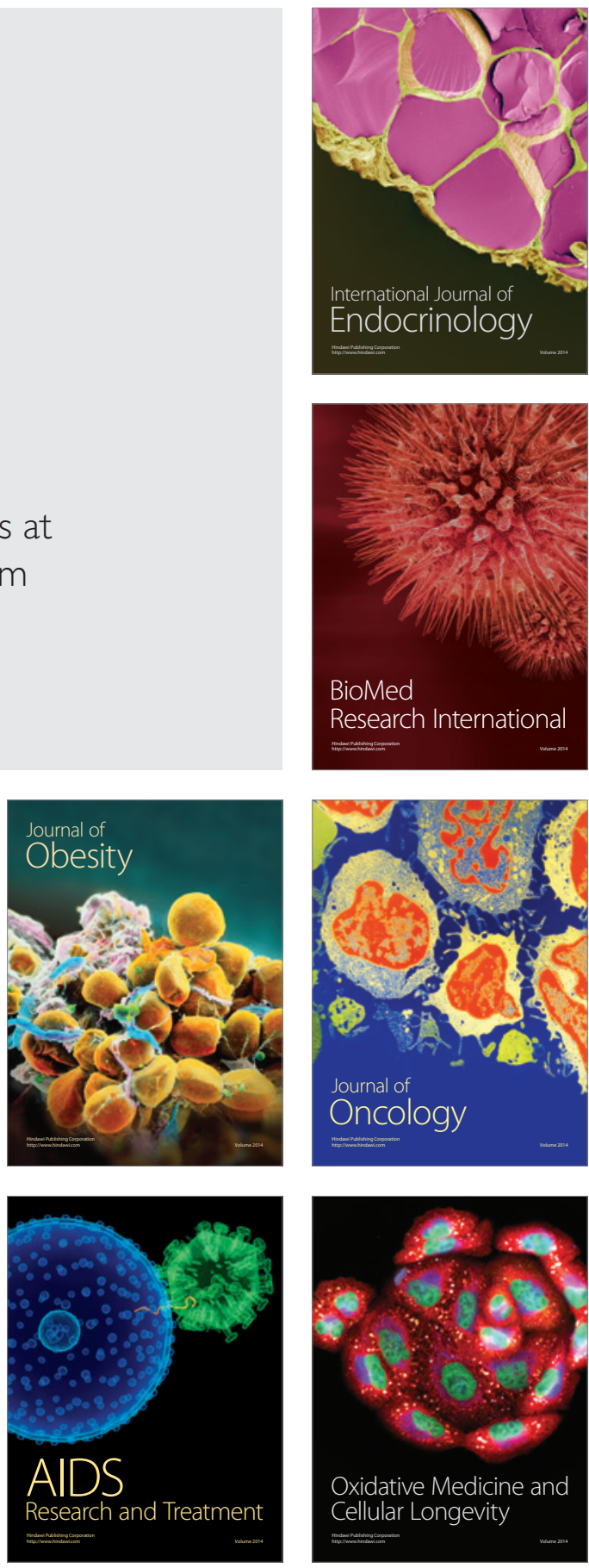